\title{
Realisasi Alat Ukur Suhu Dan Kelembapan Berbasis Raspberry Pi
}

\author{
Septian Angga Pratama ${ }^{1 *}$, Nana Subarna ${ }^{2}$ \\ ${ }^{1 * 2}$ Jurusan Teknik Elektro, Institut Teknologi Nasional Bandung \\ Jln. P.H.H. Mustapa No. 24 Bandung, telp/fax 022-7272215
}

Email: Septianangga12@gmail.com

\begin{abstract}
Temperature and humidity are one of the most frequently measured parameters. Measurements of temperature and humidity parameters are very useful for studying a physical, chemical, or biological process. In the last few decades, global warming or global warming has become a global issue related to the environment where pollution and damage to the environment are factors that cause high temperatures in the earth. Therefore the main focus of this research is about measuring the temperature and humidity of a room with a dimension of $15 \times 10 \mathrm{~m}$ whether it is necessary to have additional cooling in the room or not to know the level and level of linearity of the DHT 11 sensor that will be used to measure two parameters at once, with a microcontroller in the form of a Raspberry Pi. Measurements were made by taking 30 samples for 30 minutes, the results displayed from the monitor connected from Raspberry Pi showed that the DHT 11 sensor was not linear, namely the temperature $R^{2}=0.8221$, while the humidity $R^{2}=0.8893$ was due to the influence of temperature from outside and indoors and the influence of the quantity of humans in the room.
\end{abstract}

Keywords : DHT11, Raspberry Pi, Room, Temperature and Humidity

\begin{abstract}
Abstrak
Suhu dan kelembapan merupakan salah satu parameter yang paling sering diukur. Pengukuran terhadap parameter suhu dan kelembapan sangat berguna untuk mempelajari sebuah proses fisika, kimia, atau, biologi. Pada beberapa dekade terakhir, pemanasan global atau global warming menjadi isu global terkait lingkungan hidup dimana pencemaran dan kerusakan terhadap lingkungan menjadi faktor penyebab tingginya suhu bumi. Oleh karena itu fokus utama penelitian ini adalah mengenai pengukuran suhu dan kelembapan udara pada suatu ruangan dengan dimensi $15 \times 10 \mathrm{~m}$ apakah perlu dengan adanya tambahan pendingin pada ruangan tersebut atau tidak untuk mengetahui tingkat serta tingkat linearitas sensor DHT 11 yang akan digunakan untuk mengukur dua parameter sekaligus, dengan suatu mikrokontroller berupa Raspberry Pi. Pengukuran dilakukan dengan cara mengambil 24 sampel selama 4 jam hasil yang ditampilkan dari monitor yang terhubung dari Raspberry Pi menunjukan bahwa sensor DHT 11 tidak linier yaitu suhu $\mathrm{R}^{2}=0.8221$, sedangkan kelembaban $\mathrm{R}^{2}=0.8893$ dikarenakan adanya pengaruh suhu dari luar ruangan dan dalam ruangan serta adanya pengaruh dari kuantitas manusia yang berada di dalam ruangan tersebut.
\end{abstract}

Kata kunci : DHT11, Raspberry Pi, ruangan, suhu dan kelembapan

\section{PENDAHULUAN}

Suhu (temperature) dan kelembapan udara (humidity) merupakan beberapa parameter pengukuran yang sering digunakan dalam proses akuisisi data.Sebagai bagian inti dari proses ini, sensor memiliki peran penting dalam mengubah kuantitas yang diperoleh dari alam (bersifat analog) menjadi kuantitasyang dapat diproses oleh komputer (bersifat digital).Sensor juga menentukan seberapa 
tepat hasil yang diperoleh, dibandingkan dengan pengukuran yang sebenarnya melalui instrumen ukur.

Selain itu, isu yang sedang hangat diperbincangkan saat ini yaitu isu global warming yang menimpa bumi kita. Global warming adalah suatu peristiwa naiknya suhu udara secara global di permukaan bumi. Naiknya suhu udara dan rendahnya kelembapan ini akan mengakibatkan es di kutub utara dan selatan mencair. Mencairnya es di kutub ini akan membuat muka air laut akan menjadi tinggi yang akan membuat pulau-pulau di dunia akan tenggelam, dan daratan-daratan yang dihuni oleh manusia makin lama akan semakin menyempit. Hal ini dapat mengakibatkan kepunahan massal di bumi ini. Ini patut dipikirkan dengan serius agar tidak menimpa anak cucu di masa yang akan dating karena dampak dari suhu udara ini sangat mempengaruhi kehidupan manusia, maka pada penelitian kali ini akan fokus pada parameter suhu udara. Dalam mengukur suhu udara, harus diperlukan sebuah alat ukur yaitu sebuah termometer suhu udara, dalam dunia elektronika yang berfokus pada elektronika digital, pengukuran suatu parameter selalu dilakukan dengan menggunakan sebuah sensor [1].

Salah satu jenis sensor yang juga dapat melakukan pengukuran suhu dan kelembaban pada satu waktu adalah DHT. Sensor ini terdiri dari beberapa varian dengan varian yang sering digunakan adalah DHT11 dan DHT22. Sensor jenis ini cukup banyak dipilih karena data keluaran yang dihasilkan sudah dalam bentuk digital sehingga tidak memerlukan lagi proses konversi dari sinyal analog [2].

Tujuan dari penelitian ini adalah untuk mengetahui nilai linearitas dari pengukuran yang dihasilkan oleh sensor DHT11.

\section{METOODOLOGI}

Adapun metoda penelitian yang dilakukan untuk melakukan penelitian ini adalah sebagai berikut:

\section{Material}

Material material yang digunakan hanya tiga komponen saja, yaitu DHT11, Raspberry Pi, dan monitor. Sensor DHT11 ini berfungsi sebagai sensor yang mengukur dua parameter sekaligus yaitu suhu dan kelembapan. Raspberry Pi merupakan komputer mini yang lengkap serta telah dilengkapi dengan fiturfitur layaknya sebuah komputer lengkap, menggunakan SoC (System-on-a-chip) ARM yang dikemas dan diintegrasikan di atas PCB (papan sirkuit), sementara monitor berfungsi untuk menampilkan data yang terbaca dari sensor tersebut [3].

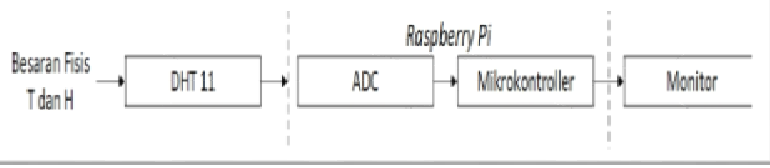

Gambar 1. Material pada penelitian

Gambar 1. Menampilkan material yang digunakan pada penelitian. Sensor DHT11 pada penelitian ini digunakan untuk mengukur suhu dan kelembapan pada ruangan yang akan diuji, kemudian data-data digital tersebut dikirimkan kepada microcontroller Raspberry Pi dengan pin GPIO 7. Microcontroller akan menerima data digital (suhu dan kelembapan) maupun data analog (tegangan) kemudian akan dikirimkan menuju monitor untuk penampilan hasil dari pembacaan sensor [4].

\section{Perancangan dan Pengujian Sistem}

Secara garis besar, perancangan yang dilakukan digambarkan pada gambar 2 .

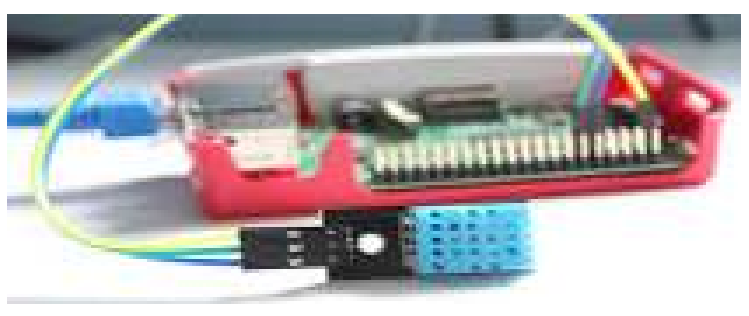

Gambar 2. Perancangan Sistem

Pada perancangan dilakukan dengan menggunakan sensor DHT11 sebagai alat 
pendeteksi suhu dan kelembapan serta Raspberry Pi sebagai mikrokontrollernya. Untuk mengetahui linearitas data yang diukur dan ditampilkan, serta mengetahui apakah ruangan yang akan diuji layak menggunakan alat elektronik tambahaan seperti AC dan kipas angin, maka dilakukan pengujian dengan mengukur suhu dan kelembapan ruangan menggunakan sensor DHT11. Pengujian suhu dapat dilihat pada gambar 2, pengujian ruangan data yang sudah terbaca pada monitor kemudian dilakukan pengambilan data dalam 24 sampel selama 4 jam untuk mengetahui tingkat linearitas dari sensor serta suhu dan kelembapan dari ruangan yang diuji, berikut data yang diperoleh dapat dilihat pada tabel 1 .

Tabel 1. Suhu dan Kelembapan pada ruangan yang

\begin{tabular}{ccc}
\multicolumn{2}{c}{ diuji. } & \\
\hline No. & Suhu( $\left.{ }^{\circ} \mathbf{C}\right)$ & Kelembapan(\%) \\
\hline 1 & 23.5 & 58 \\
2 & 23.6 & 58 \\
3 & 23.5 & 58 \\
4 & 23.6 & 58 \\
5 & 23.7 & 58 \\
6 & 23.7 & 58 \\
7 & 23.7 & 58 \\
8 & 23.7 & 57 \\
9 & 23.8 & 57 \\
10 & 23.8 & 57 \\
11 & 23.9 & 57 \\
12 & 23.9 & 57 \\
13 & 24 & 57 \\
14 & 24 & 57 \\
15 & 24.2 & 57 \\
16 & 24.3 & 57 \\
17 & 24.5 & 56 \\
18 & 24.9 & 56 \\
19 & 25 & 56 \\
20 & 25.2 & 56 \\
21 & 24.8 & 56 \\
22 & 24.7 & 56 \\
23 & 24.7 & 57 \\
24 & 24.5 & 57 \\
\hline
\end{tabular}

\section{HASIL DAN PEMBAHASAN}

Hasil Analisis yang dilihat dari grafik di atas, menghasilkan nilai suhu dan kelembaban yang stabil, serta data yang didapat mengakibatkan sensor tersebut bisa dikatakan non linier karena $R 2$ yang didapat dari masingmasing grafik $<1$ hal ini dikarenakan karena adanya pengaruh suhu dari luar serta kuantitas dari manusia yang berada pada ruangan tersebut.

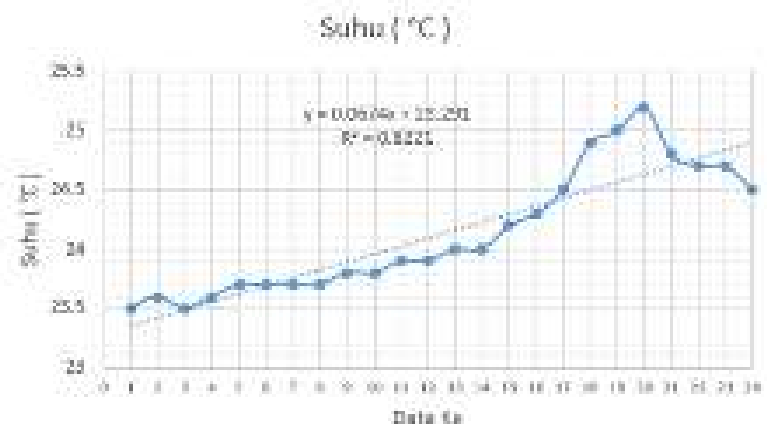

Gambar 3 . Linearitas Suhu

Dilihat dari Gambar 3. data yang didapat linearitas suhu $R 2=0.8221$.

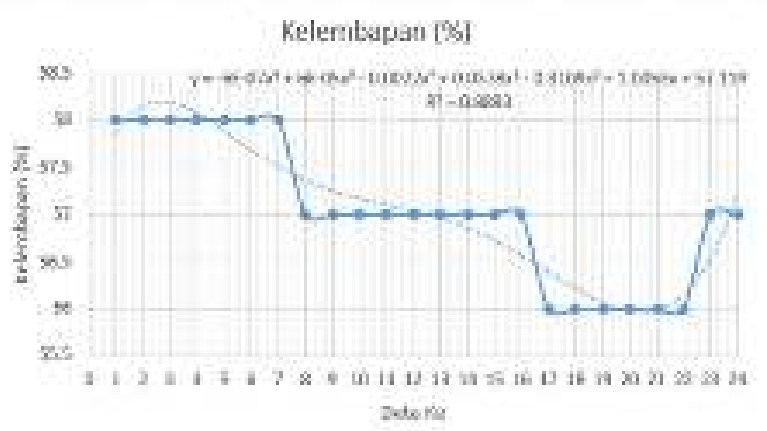

Gambar 4. Linearitas Kelembapan

Data yang terlihat pada Gambar 4. didapat kelembapan $R 2=0.8893$.

\section{KESIMPULAN}

Pada penelitian ini tingkat linearitas dari sensor tersebut, dikatakan bahwa sensor DHT11 merupakan sensor non-linear, hal ini dikarenakan data yang di dapat dari grafik menunjukan stabilnya suhu dan kelembapan karena tubuh manusia jika suhu $\pm 1{ }^{\circ} \mathrm{C}$ tidak akan berpengaruh dan kelembapan juga sama jika $\pm 1 \%$ tidak akan berpengaruh pada tubuh manusia, walaupun suhu dan kelembapan mengalami kenaikan atau penurunan.

Dapat disimpulkan bahwa setelah melakukan pengujian selama 4 jam dan didapat 24 data pada ruangan tersebut, dikatakan bahwa ruangan tersebut memerlukan 
adanya pendingin ruangan baik $\mathrm{AC}$ ataupun kipas angin, supaya ruangan tersebut ketika semakin siang tidak terlalu panas.

\section{SARAN}

Untuk meningkatkan kualitas alat yang dibuat, maka dapat dilakukan beberapa pengembangan seperti:

1. Merancang sistem yang berbasis Internet of Things (IoT) yang khusus diperuntukkan untuk memantau nilai suhu dan kelembaban yang teruji pada 2 ruangan secara bersamaan.

2. Pembuatan sistem monitoring selain dengan IoT dapat digunakan dengan tampilan pada web yang menampilkan nilai suhu dan kelembapan pada ruangan dari jarak jauh.

\section{DAFTAR PUSTAKA}

[1] Alif, Y. K. U. "Perbandingan Kualitas Antar Sensor Suhu dengan Menggunakan Arduino Pro Mini" dalam e-Jurnal NARODROID, Vol. 2 No.2 Juli 2016 EISSN : 2407-7712.

[2] Hendra, A. S. "Perbandingan Akurasi Pengukuran Suhu dan Kelembaban Antara Sensor DHT11 dan DHT22" dalam Jurnal Infotel Vol. 6 No. 2 November 2014.

[3] Dewi , Ika Kumala . (2016). "Pengertian Raspberry".<https://ikakumaladewi.wordpr ess.com/2016/09/29/makalah-raspberry/>.

[4] Triputranda, Aldi, "Monitoring Suhu Ruangan Server Berbasis Raspberry $\mathrm{Pi}$ Menggunakan Suhu DHT11, Palembang: Politeknik Negeri Sriwijaya Repository, 2016. 